University of Louisville

ThinkIR: The University of Louisville's Institutional Repository

Faculty Scholarship

8-4-2021

\title{
A Woman's Optics: Margaret Cavendish, Sensory Mimesis, and Early Modern Rhetorics of Science
}

Megan Poole

University of Louisville, megan.poole@louisville.edu

Follow this and additional works at: https://ir.library.louisville.edu/faculty

Part of the Rhetoric Commons

\section{Original Publication Information}

Poole, Megan. "A Woman's Optics: Margaret Cavendish, Sensory Mimesis, and Early Modern Rhetorics of Science." 2021 Journal for the History of Rhetoric, 24(2):195-222.

ThinkIR Citation

Poole, Megan, "A Woman's Optics: Margaret Cavendish, Sensory Mimesis, and Early Modern Rhetorics of Science" (2021). Faculty Scholarship. 546.

https://ir.library.louisville.edu/faculty/546

This Article is brought to you for free and open access by ThinkIR: The University of Louisville's Institutional Repository. It has been accepted for inclusion in Faculty Scholarship by an authorized administrator of ThinkIR: The University of Louisville's Institutional Repository. For more information, please contact thinkir@louisville.edu. 


\section{A Woman's Optics:}

\section{Margaret Cavendish, Sensory Mimesis, and Early Modern Rhetorics of Science}

It is the great prerogative of Mankind above other Creatures, that we are not only able to behold the works of Nature ... but we have also the power of considering, comparing, altering, assisting, and improving them to various uses. And as this is the peculiar privilege of humane Nature in general, so is it capable of being so far advanced by the helps of Art, and Experience, as to make some Men excel others in their Observations, and Deductions, almost as much as they do Beasts.

Robert Hooke, 1665, Micrographia, p. 1

But the all-powerful God, and his servant nature, know that art [artificial means], which is but a particular creature, cannot inform us of the truth of the infinite parts of nature, being but finite itself.

Margaret Cavendish, 1666b, Observations, p. 48

On May 30, 1667, the experimental methods of the Royal Society of London were placed on display during a historic meeting. Robert Boyle, then Curator of Experiments, set up a microscope and prepared to present a miniscule view of various natural elements for that day's meeting attendees. The experiments were meant to showcase what he and fellow member of the Royal Society, Robert Hooke, considered as "the great prerogative of Mankind," that of beholding nature in its constitutive parts. Royal Society members, of course, were no strangers to a microscopic view of matter, due to the rising popularity of the device following the success of Robert Hooke's Micrographia (1665), the organization's first major publication by one of its members. Nevertheless, the energy of the room was more frenzied than usual that day, and Boyle had to halt his presentation, as it was meant for the eyes of one particular observer who had yet to arrive. Rarely did 
the Royal Society extend invitations to non-members, but this visitor had composed an emphatic critique of experimental natural philosophy, specifically the optics theorized in Boyle and Hooke's work. So everyone waited, hoping to proffer the undeniable benefits of the microscope to their critic, Margaret Cavendish. Cavendish, however, would arrive over an hour late, her words would be few, and it would be her last meeting at the Royal Society.

When Cavendish accepted this invitation, she became the first woman to attend a meeting at the Royal Society. Considering that women would not receive election to join the organization until 1945 (Royal Society n.d.), Cavendish's presence at this meeting marks an important moment in histories and rhetorics of science. As Cavendish openly and harshly critiqued the Royal Society's epistemic practices in Observations (1666), she did so at a time when most women's opinions were all too easy to dismiss. Her marriage to William Cavendish, however, afforded opportunities not usually extended to women in early modern England: she became "Duchess of Newcastle," gained entry into an elite group of thinkers surrounding her husband known as the "Cavendish Circle, which would regularly include the likes of Rene Descartes and Thomas Hobbes (Cunning 2017, para. 3), and acquired the ability to publish and print her philosophical, scientific, and literary work. ${ }^{1}$ Of course, that central place in the public eye led to Cavendish's reputation as little more than a spectacle to her contemporaries (Lilley 1992, ix).

\footnotetext{
${ }^{1}$ Tina Skouen and Ryan J. Stark report that Cavendish was "the first and the only Englishwoman of the period to publish works in natural philosophy in her own name" (Skouen and Stark, 2015, 13). A recent collection by Leah Knight, Micheline White, and Elizabeth Sauer (2018), Women's Bookscapes in Early Modern Britain, sheds light on the writing, publishing, and reading practices of early modern women, and Julie Crawford
} 
Because of her social status and prolific authorship, members of the Society, such as Samuel Pepys, continually sought and failed to make Cavendish's acquaintance. Once when she rode into the city, Pepys and a large crowd of others gathered to view her arrival, but, Pepys described, "we could not, she being fallowed and crowded upon by coaches all the way she went, that nobody could come near her" $(1667,196)$. Recognizing her influence and knowing her "desire to be present at one of the meetings of the Society," another Society member and member of Parliament, Lord George Berkeley, made a request on May 23, 1667 to extend a meeting invitation to Cavendish (Birch 1756, 176). Much debate ensued, as some feared that the event would make a mockery of the Society (Mintz 1952, 171-72). Mockery or not, from the moment Berkeley's request was granted, everyone knew that the event would spark controversy throughout London.

When Cavendish did finally arrive on May 30, 1667, it was "with glorious train and gilded coach, and horse with many a tassle" (Whitaker 2003, 299). She was met at the door by the President of the Society, Lord Brouncker, and seated next to him for the entirety of the meeting. Pepys and the other members watched Cavendish with intent and eagerly awaited her response to Boyle's experiments. Her reaction, they anticipated, would be as fiery as her written critiques. Instead, as Pepys chronicles, "I [did not] hear her say any thing that was worth hearing, but that she was full of admiration, all admiration.... After they had shown her many experiments, and she cried still she was

uncovers how Cavendish was especially strategic in the distributing of her texts, ensuring that certain university libraries maintained copies of her folios (Crawford, 2018, 114). This care taken to consider the longevity of her work shows that Cavendish viewed her ideas as compendiums to other established texts in the universities like Hooke's. 
full of admiration, she departed" (Pepys 1667, 243). Scholarly depictions of her performance that day present Cavendish as "plagued by shyness" (Whitaker 2003, 290) and "afflicted with her usual bashfulness" (Sutherland 1997, 269). This depiction of Cavendish's visit to the Royal Society as a let down has clouded how historians of rhetoric interpret her scientific writing.

Cavendish is often considered a "practitioner of rhetoric," one who aspired to the rhetorical tradition but who "never developed a coherent theory of it" (Sutherland 1997, 255; Kennedy, 1999, 263). Rather, the rhetorical tradition running through early modern England, George A. Kennedy explains, centered instead on Hobbes, Locke, and the "new logic" of the Royal Society. Because this new Baconian logic was channeled through the "plain" scientific prose of experimental philosophy, Cavendish's stylistic flourishes and "flights of fancy" were widely dismissed in her time (Stark 1999; Nate 2001). Hui Wu further explains that the problem with studying Cavendish in contemporary rhetorical scholarship is that her work does not quite "meet the criteria of [the] rhetorical tradition and academic feminism" (2005, 171). I argue that finding Cavendish's most substantial contribution in the history of rhetoric may not come from examining the traditional rhetorical artifacts that these scholars have queried, namely her novellas, poetry, and general treatises. Instead, Cavendish's contributions to rhetoric come to fore through her scientific writing, through her critique of Hooke's Micrographia, her reimagining of early modern metaphysics, and her theorization of an alternative optics to counter that of the Royal Society's. 
Teasing out the details of this alternative optics requires, admittedly, a bit of critical imagination. In Feminist Rhetorical Practices, Jacqueline Jones Royster and Gesa E. Kirsch define critical imagination as a methodology employed to speculate on existing evidence (2012, 71). The first step in employing critical imagination, they explain, is "gathering whatever evidence can be gathered and ordering it in a configuration that is reasonable and justifiable in accord with basic scholarly methodologies" (Royster and Kirsch 2012, 71). The second step is then thinking "between, above, around, and beyond this evidence to speculate methodically about probabilities" (Royster and Kirsch 2012, 71). In the case of Cavendish, established evidence has centered almost exclusively on The World's Olio, Orations of Divers Sorts, and The Blazing World. However, gathering new evidence through her theories of experimental philosophy explicated in Observations on Experimental Philosophy reveals two unconsidered elements of her work to scholars in the history of rhetoric and rhetorics of science. First, Cavendish's famous debate with Hooke and the Royal Society was primarily a contention centered on optics and new ways of seeing emerging around the microscope. Second, the rhetorical and poetic concept of mimesis offered Cavendish the epistemological confidence needed to critique the optics of the Royal Society. Whereas the optics of the Royal Society created distance and difference between the observer and the object of study, Cavendish's optics would connect the observer with the natural world through a theory of mimetic patterning.

Cavendish's critiques of Renaissance epistemologies through her own alternative science thus offers a new angle from which to consider what Jeanne Fahnestock has argued in Rhetorical Figures in Science, namely that rhetorical concepts have structured 
scientific thinking, particularly in scientific paradigm shifts. Here, I argue that mimesis helped Cavendish to anticipate a scientific epistemology more accessible to early modern women in how the term allowed her to envision an expansion of agency in scientific study that extended beyond the traditional scientific observer. To uncover the rhetorical underpinnings of Cavendish's optics, I first track Cavendish's points of contention with Hooke's Micrographia, presenting her critique as itself a rhetoric of science, however one concerned less with Hooke's argumentation style as with his pedagogy of sight. Next, I explicate Cavendish's unique theory of optics based around her concept of "patterning," which I argue is an extension of rhetorical mimesis or "imitation." Finally, I consider how the rhetorical concept of mimesis allowed Cavendish to cast a skeptical glance at science and imagine alternate ways of knowing that anticipated feminist science studies. Thus, reviving Cavendish's science offers an extended analysis of the rhetorical valences of one woman's embodied, material optics.

\section{Artless Microscopy and the Bodily Work of Observation}

With their motto "Nullius in verba," which was translated as "take nobody's word for it" (Royal Society n.d., para. 3), notable members of the Royal Society soon became the definitive authority among experimental philosophers after the establishment of the learned collective in 166o. Its mission brought members like Boyle and Hooke to verify all statements concerning the natural world through what Jordynn Jack calls "new empirical evidence" to support their theories (Jack 2009, 194). In the case of the microscope, this new empirical evidence derived from the ability to see the minutiae of matter. Hooke's first collection of microscopic images-Micrographia—showcased fleas, charcoal, and 
other natural entities through refractive lenses, as seen in Figures 1 and 2, and presented the idea that technological instruments like the microscope extended the human senses, rendering visible elements of matter that were previously imperceptible. Accompanying Hooke’s images, Jack explains, was a "pedagogy of sight" that instructed viewers how to interpret images through the Royal Society's epistemic framework. The microscope, and the ways of seeing emerging alongside it, required that scientists related to their objects mechanistically. Only premises that could be mechanistically observed were considered as the kind of "proof" necessary to validate one's hypothesis.

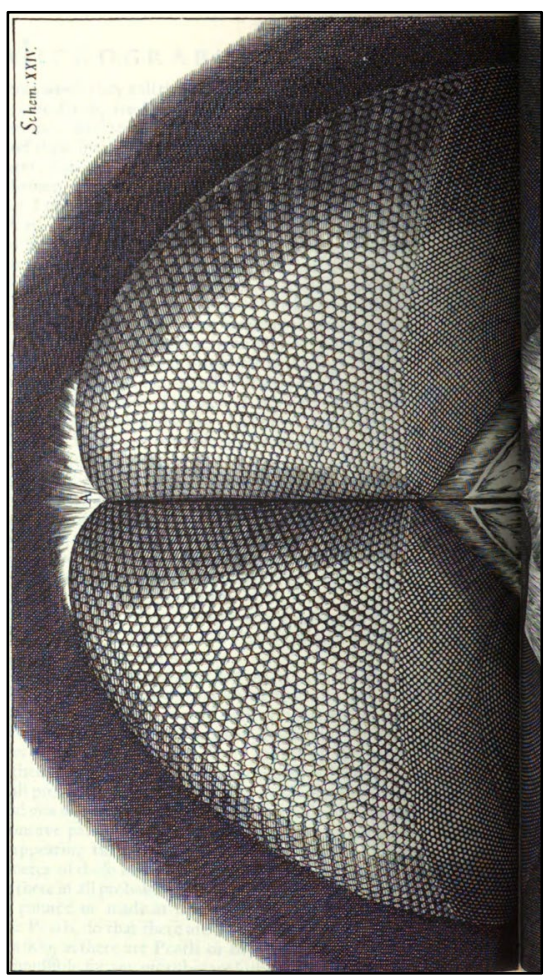

Figure 1. The Eyes of a Grey Drone-Fly. (Hooke 1665, 252)

Only aristocratic, educated males, however, or those who comprised the membership of the Royal Society, were extended the opportunity to use these scientific tools for intellectual ends-an exclusivity that often prevented women and people of lower classes from wielding argumentative authority. In effect, historian Eve Keller argues, the microscope was

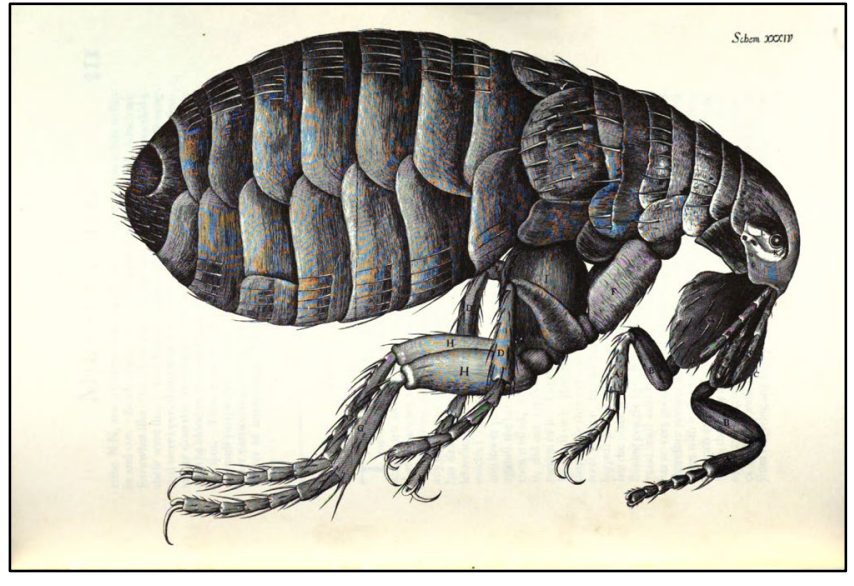

Figure 2. Observation of a Flea. (Hooke 1665, 307) therefore less about discovering the "truth" of nature and more about producing men as "petty gods" $(1997,467)$. In turn, Cavendish’s antagonism with the Royal Society had less 
to do with what could be seen by the microscope and more to do with the "pride of place that she saw some experimentalists giving to empirical observation" (Marshall 2016, xii). This pride of place, too, brings Alan Gross to describe Micrographia as deliberative rhetoric, in part didactic science, but largely an exhortation for readers to support the ideals of the Royal Society (2016, 17-18). That is, Micrographia was less a scientific manual than a persuasive text designed to show the Royal Society and its natural philosophers as trusted and respected discoverers of "God's handiwork" (Gross, 2016, 19).

By zeroing in on the Society's first major publication, Cavendish signaled that her message not only targeted Hooke's "artificial means" via the microscope, but also the epistemological foundations of this emerging science. Cavendish thus entered into larger Renaissance conversations regarding the relationship between "art" and nature as well as the origins of knowledge itself. Historian of early modern philosophy Sarah Hutton depicts this particular historical moment as "a time of enormous intellectual ferment," a time when predominant Aristotelian paradigms of knowledge were being challenged by the emergent philosophies of Descartes, Hobbes, and others (2003, 186-187). These new philosophies questioned whether and how human knowledge could be certain of that which it ascertained. At least for Cavendish, the main foci of these debates-the relationship between art and nature, the status of knowledge, and the role of sensation in knowledge-converged in the technology of the microscope. The microscope became a nexus on which Cavendish could base an alternative scientific epistemology and theory of optics. 
In Observations, Cavendish leveled a three-fold critique against Hooke's optics in Micrographia: 1) the degree of authority given to "art"; 2) the depiction of the human senses as in need of extension and correction through microscopy, a tenet that disavowed contemplative philosophy as a reputable method of scientific inquiry; 3) the claim that nature's "internal substance" could be derived from microscopic images. As she engaged with Hooke, Cavendish argued that attentive sensing could lead to reputable scientific discoveries. If Hooke contended that theorists must use microscopy to contribute to scientific knowledge, then Cavendish would theorize an optics in which observation was not a specialization, and in which the apparatus used to discover scientific truths was natural to both men and women. According to Cavendish's scientific epistemology, the truest knowledge came primarily through the body's biological way of sensing, through the lenses of the eye, rather than through mechanical instruments. ${ }^{2}$

The Authority of "Art"

In the opening of Observations, Cavendish quoted a portion of Hooke's preface in Micrographia to center her critique and expose Hooke's belief that human sensation was prone to error, able to lead the mind toward inaccurate reasoning. Here, I include that

${ }^{2}$ Cavendish's engagement with Hooke was certainly a matter of "optics." Although modern conceptions of optics relate to physics-reflection, refraction, and how light enters the eye-this shift in focus from sight to light is a relatively recent occurrence in the history of optics, explains historian A. Mark Smith. Smith traces the etymology of the Greek optika to opteū ("to see") and both words to ops ("eye") $(2015,25)$. Only with Kepler's theorization of the retinal image, Smith argues, did the study of optics become more concerned with light than with sight. In early modern England, then, Cavendish would have conceived of her explication of Hooke's way of seeing and her own theory of visual perception as a theory of optics. 
section of Hooke's preface at length to show the repetitive insistence on the "mischiefs," "imperfections," and "errors" of the senses by which "art" is meant to make reparation:

By the addition of such artificial Instruments and methods, there may be, in some manner, a reparation made for the mischiefs, and imperfection, mankind has drawn upon it self, by negligence, and intemperance, and a wilful and superstitious deserting the Prescripts and Rules of Nature, whereby every man, both from a deriv'd corruption, innate and born with him, and from his breeding and converse with men, is very subject to slip into all sorts of errors. (Hooke 1665, 1)

Only the scientific expert—-the one who has properly applied reason and artificial means to nature-Hooke's epistemology entailed, might come to accurate scientific conclusions. Cavendish maintained, in her rebuttal to the passage, that reparations are not so easily made, precisely because all "art" was as finite as the conclusions of a sensing human observer. Cavendish would instead emphasize the finitude of "art," as she put it: "But the all-powerful God, and his servant nature, know, that art, which is but a particular creature, cannot inform us of the truth of the infinite parts of nature, being but finite itself" (Cavendish 1666b, 5). The artificial, according to Cavendish, could never supersede the natural.

If one central question guided Cavendish's thought in Observations it was to what extent art could alter nature, suggests historian of philosophy Susan James (James, 2018, 31). According to Aristotelian metaphysics, art could imitate nature, but not equal or surpass it (James, 2018, 31). Hooke's microscopy contended instead that art could indeed transform nature, insisting that by artificial means, "the Heavens are open'd, ... and new Productions appear in them, to which the ancient Astronomers were utterly Strangers" (Hooke, 1665, 4). According to Cavendish, however, microscopes offered a view of life in cross section, a partial perspective that "doth more easily alter than inform" (Cavendish 
1666b, 50). Such microscopic slices on which Hooke and others based their reasoning was not "pure nature," but what Cavendish called "hermaphroditical mixtures," termed as such because the results of microscopy were, as she put it, "partly natural, and partly artificial" (Cavendish 1666b, 197). Of course, definitions of where nature ended and art began were quite blurry for Renaissance thinkers, and for Cavendish, the more fundamental question was whether such lines should be drawn in the first place.

As with other foundational ideas in the "new logic" of the Royal Society, a touchstone in art/nature distinctions can be found in the work of Francis Bacon. As historian Sophie Weeks details, Bacon authored careful redefinitions of "nature" and "art" as he challenged the traditional Aristotelian narrative of art as imitative of nature (Weeks, 2007, 106). As Weeks purports, nature, according to Bacon, had endless possibilities, of which only one possibility might be actualized at a time. Art brought to fore those alternative possibilities, evoking that which lay nascent. The ultimate goal of Bacon's new science, then, was to "obliterate nature's habitual courses" through "the systematic unveiling of [its] hidden facets" (Weeks, 2007, 128). The problem for Cavendish was not that art could reveal nature but that art came to be seen as the best, if not the only, method for revealing nature. Nature, in other words, was stripped of the power to reveal itself, to speak in its own right. And if nature could not speak directly to human intuition, then, among other implications, women had no means by which to listen.

In looking at how Hooke theorized from the slices of life offered by mechanical means, Cavendish perceived how a hierarchy might emerge in the relationship between scientists and their objects of study. In championing how the microscope extended the 
senses and granted dominion over nature, Royal Society members like Hooke were, at least in Cavendish's estimation, forgetting their own status as finite parts of the same nature" they sought to understand, suggests historian and philosopher of science Ian Lawson $(2015,595)$. Anaesthetizing what was placed beneath the microscope, dissecting life and bringing it to stillness, allowed the scientist to emerge as seemingly the only active agent in scientific encounters. To be clear, Cavendish's difficulty was not so much with only seeing a slice of the object as with how the object was primarily studied in its static, specimen-form as well as how such a slice seemed to ignore the synoptic environment from which the object was extracted. ${ }^{3}$ For Cavendish, truth of the natural world could only be ascertained if objects were studied in their living form, moving throughout its environment and interacting with the other agents therein.

Hobbes, the thinker who perhaps had the most influence on Cavendish's own natural philosophy and who pushed against the metaphysics of the Royal Society as staunchly as Cavendish, would also make the relationship between art and nature central to his philosophy. 4 This relationship was perhaps best captured in Hobbes's analogy of

3 Hooke's theory of vision, it should also be noted, was not altogether different from Cavendish's. Christa Knellwolf explains that for Hooke, vision was "a mechanical process of registering corpuscular light which, in the mind, produces Ideas which he 'suppose[s] to be material and bulky"' (Knellwolf 2001, 195). Ian Lawson further argues that "Hooke's aim was never to ... share with his readers ... a realistic impression of sight with a microscope, but his privileged knowledge of the microworld" (Lawson 2016, 39). The key difference in their respective optics is that Hooke had no conception of sense organs as patterning objects' internal motion.

${ }^{4}$ Hobbes, it seems, was at least Cavendish's earliest philosophical influence, according to Eileen O'Neill. Hobbes served as her husband's tutor in his youth, and Hobbes remained close to the family thereafter as a main figure of the "Newcastle Circle" and as the Newcastle family served as his patrons (O’Neill, 1998; Detleftsen, 2007). Remnants of 
the "artificial man," which posited that the mechanical, mathematical laws that govern the universe may also govern human behavior (Ankers 2003, 246). Art as part of nature allowed humans to work within nature, to bring nature to its best possible end (Walton 1987, 71). Case in point was how Hobbes considered rhetoric as one such art that might perfect humans' natural tendencies. Arts like rhetoric, argues historian of rhetoric Ned O'Gorman, served as a means for transcending and thus overcoming what Hobbes considered as humans' "hostile natural condition" (O'Gorman 2013, 5). As O'Gorman further explains, rhetoric, for Hobbes, "does not improve upon nature so much as recreate a natural pattern on an artificial plane so as to overcome what 'evill men' do naturally (O'Gorman 2013, 5). Artificial man, that individual able to overcome his nature, thus became a model of civil society, one in which nature, the individual, and society were unified (Ankers 2003, 246). Obeying authority, the idea went, was like obeying the laws of nature, and obeying the laws of nature was conforming to an inevitable, immutable logic (Ankers 2003, 247). Such emphasis on mechanism, however, brought Cavendish to consider artificial man as an analogy that sought to limit nature. Cavendish's philosophy, then, would take Hobbes's "artificial man" analogy and counter it to depict nature as an agential actor. As Neil Ankers shows: “Cavendish appropriates Hobbes's 'artificial man' analogy and applies it to nature rather than to the nation state or 'commonwealth"'

Hobbes's materialism is evident as a central undercurrent in Cavendish's thought, yet she went to great lengths to distance herself from him, writing against his theories at times and denying that she knew him well at others. Once Cavendish even wrote that she had never read more than 20 words of Hobbes (Hutton, 1997). 
(Ankers 2003, 247). That is, nature was given the non-mechanical agency and autonomy of human individuals (Ankers 2003, 247).

The issue of agency in the relationship between art and nature was of utmost importance to Cavendish precisely because of her positionality as "Mad Madge," or as a woman without formal education whose ideas were rarely taken seriously. The artificial powers for overcoming nature-such as rhetoric or the mechanical means of the microscope-were not as fully afforded to her. By Hobbes's and Hooke's systems, Cavendish could never achieve the status of "artificial man." The competing epistemologies circulating in Renaissance thought, explains historian Eileen O'Neill, all entailed gendered mechanisms that discredited women's ways of knowing and "all [had] in common the habit of ignoring and disparaging the experience and reality of women" (O'Neill, 1998, 95). Cavendish's metaphysics, then, would have to be one in which the powers of rhetoric and the powers of observation, here inextricable, were afforded through nature itself-a metaphysics in which nature, and thus natural ways of knowing, were in need of no perfecting.

The Knowledge of Sensation

Of all the thinkers who contested the philosophical and scientific work of the Royal Society as it was emerging, Cavendish's critique was the one that "constitutes the century's most dramatic attempt to bend the discourse of [the Royal Society] to a radical cultural end," according to literary studies scholar John Rogers $(1996,181) .5$ Cavendish's

\footnotetext{
${ }^{5}$ Many elements of the Royal Society's philosophical and scientific views were under contestation in Cavendish's "attempt to bend [their] discourse." Here particularly Rogers is speaking of the Society's "monistic materialism," or the idea that all matter is
} 
particular style of scientific inquiry has been defined as "full-scale skepticism" (Sarasohn 1984, 292), a "science of the fancy" meant to "restore the balance in an age of reason" (Bowerbank 1984, 406). Because, as Lisa T. Sarasohn puts it, "the path to conventional knowledge was closed to her" $(1984,292)$, Cavendish subverted established scientific epistemologies and practices, calling into question what science was and who could be considered a scientist. Whereas the experimental philosophers of the Royal Society sought methods for approaching nature through systematic and mechanical means, Cavendish practiced imaginative, speculative, and embodied ways of knowing, and her "justification for her lack of method [was] that she recreate[d] pure nature" (Bowerbank 1984, 396). For Cavendish, arriving at the truth of nature could only come through direct sensory encounters with natural phenomena, discovering nature through biological apparatuses, not "artistic" means like the microscope.

In a time in which the status of knowledge itself was subject to debate, Cavendish saw an opportunity to put forth imaginative, intuitive, and embodied ways of sensing and knowing as reputable methods of inquiry. "If no one can know anything absolutely," Sarasohn articulates, "then there was no reason why [Cavendish's] speculations might not be as correct or more correct than anyone else's" (Sarasohn, 1984, 292-293). This instance on skepticism emerged at the time in which epistemology — that inquiry into what

composed of a single element that was subordinated and organized by God (Rogers 1996, 6). In contrast to monistic materialism, Cavendish adopted a "vitalist" view of matter. Vitalism contended that all matter was composed of self-moving, animate matter and that these many elements of matter might not always cohere into a unified whole (Marshall 2016, xvi). Other scholars define Cavendish's view of matter as "panpsychist" (Broad 2011, 459). Still others define it as "vitalist materialism" (Boyle 2018, 62-63). 
knowledge was, where it came from, and how humans could be certain of it-was becoming central in Renaissance thought. Yet epistemology was becoming central, historian Richard H. Popkin explains, precisely because skeptics like Cavendish continually leveled challenges against every new way of thinking (Popkin 1988, 684). ${ }^{6}$ Established Aristotelian thought detailed that knowledge was first attained through sensory activity, then abstracted into objects via the intellect, and finally known conceptually. As we know, natural philosophers in the vein of the Royal Society broke with this theory and argued that individuals must develop "a special power for experiencing or apprehending the real nature of things" (Popkin 1988, 677), such special powers coming, of course, from experimental methods and artificial means. Still others called into question whether any human knowledge could be certain. Whereas NeoPlatonists contended that full knowledge could never be acquired because that knowledge exceeded our human finitude, skeptics maintained that "perfect knowledge of a thing" might arrive "by immediate intuitive apprehension" (Popkin 1988, 673; 682). Erring on the side of this synoptic, intuitive knowledge, Cavendish would find the knowledge claims of natural philosophers too limited by their selections, or slices of life. Cavendish's contention with Hooke and the Royal Society's experimental natural philosophy was that observation through microscopy, or artificial means, disallowed

${ }^{6}$ In many respects, Cavendish's theories parallel the ideas expressed by Francisco Sanches, the skeptic and cousin of Michel de Montaigne, who argued that true scientific knowledge could never be acquired because all that humans could attain was "a limited knowledge of some things in the present" (Popkin, 1988, 682). The revised skepticism of Sanches and Montaigne, Popkin contends, became the challenge that must be met for those philosophers seeking a new foundation of knowledge (Popkin, 1988, 684). 
individuals to sense the "whole" of natural phenomena. Hooke would maintain that without artificial means it was impossible to have complete understanding of nature: "Not having a full sensation of the Object, we must be very lame and imperfect in our conceptions of it, and in all the propositions which we built upon it" (Hooke 1665, 2, emphasis added). "Full sensation" was not something of which the human sensory apparatus was capable, Hooke would insist. And this fallibility of the senses would further impact the mechanism of memory and the mind: "Thus all uncertainty, and mistakes of humane actions, proceed either from the narrowness and wandring of our Senses, from the slipperiness or delusion of our Memory, [or] from the confinement or rashness of our Understanding" (Hooke 1665,3$)$. Properly wedding the senses to reason, or understanding, through "art" would bring experimental philosophers to more truthful methods of induction. In order to counter this epistemology, Cavendish would trouble this relationship to the senses and query whether and how knowledge could be acquired through sensation. For in Cavendish's estimation, knowledge that came through natural processes like sensation must be credited if her mimetic epistemology or methods like contemplative philosophy could ever be legitimized.

Her rebuttal was that extending the senses through "art" provided no such infallible reason or understanding. As she would reiterate, because "art" is "apt to delude sense," it "cannot inform so well as reason doth" (Cavendish 1666b, 47). Cavendish further problematized Hooke's sense/reason hypothesis by insisting that "sense, which is more apt to be deluded than reason, cannot be the ground of reason, no more than art [artificial means] can be the ground of nature.... For how can a fool order his 
understanding by art, if nature has made [his understanding] defective?" (Cavendish 1666b, 49). To put it another way, even though artificial means extended the senses, they were still subject to the fallibility of the senses. Unable to bring a scientist beyond sense, the microscope could not bring them beyond reason either. Consider, she asked of her readers, the widely varying results experimental philosophers accrued when they set out to observe the same objects at different times throughout the day. If truth were to be discoverable through the microscope, then it should not be altered given different conditions, as Cavendish lamented: "Artists do confess themselves, that flies, and the like, will appear of several figures or shapes, according to the several reflections, refractions, mediums and positions of several lights; which if so, how can they tell or judge which is the truest light, position, or medium, that doth present the object naturally as it is?" (Cavendish 1666b, 51). In so many words, Cavendish argued that with the variability of the natural world, replicability with these early microscopes would be nearly impossible. Thus experimental philosophers, in her estimation, should not declare that they have observed nature in its "true form" if they are unable to replicate their observations. "Art," merely a tool for gathering different information from the natural world, could not provide holistic or more truthful information. Through their tools, experimental philosophers might better understand the molecular components of matter, but they were only able to say that matter was composed of minute building blocks, not how or why they contained them. For Cavendish, knowing more did not entail knowing better, and it certainly did not mean knowing all. 
The intuitive, synoptic method of knowing favored by Cavendish was a contemplative philosophy—a way of knowing through reflection that Hooke frequently dismissed as unable to make valuable contributions to science. Hooke expressed his distaste for contemplative philosophy in Micrographia when he cautioned: "The truth is, the Science of Nature has been already too long made only a work of the Brain and the Fancy: It is now high time that it should return to the plainness and soundness of Observations on material and obvious things" (Hooke 1665, 5). He further remarked that any observer must "make use of the same method by the Senses," via deduction through the microscope, if they were to contend with his experimental findings or "venture to compare the reality and the usefulness of his services, towards the true Philosophy, with those other men, that are of much stronger, and more acute speculations" (Hooke 1665, 5). In other words, the apparatuses used to validate scientific hypotheses were no longer found in biological ways of sensing or in everyday ways of seeing. Instead, such validation was to be found only in mechanical apparatuses. To mark microscopy and other experimental tools as the only valid means by which to remark upon natural philosophy specialized the field and placed its authority beyond the reach for many in early modern England.

With this new requirement for specialization, women, who already had little access to education, much less to optical tools, would find themselves even further removed from the realm of scientific knowledge. Cavendish reacted to this specialization by asking experimental philosophers to extend women the chance to stand on the same 
epistemic ground. And she anticipated Hooke and other philosophers' critiques as she entreated:

Whether [women] would find out the philosophers' stone, I doubt; for our sex is more apt to waste, than to make gold: However, I would have them try, especially those that have means to spend; for who knows but women might be more happy in finding it out, than man; and then would men have reason to employ their time in more profitable studies than in useless experiments. (Cavendish 1666b, 106)

Cavendish here suggested that should women pursue experimental natural philosophy, then men could go on to apply their reason for other, more "important" sociocultural matters. Women, after all, have access to the sensory system just as much as men, and should they thus become a resource for scientific inquiry, men need no longer waste their time tinkering with "artificial means."

To clarify, Cavendish did not entirely disagree with Hooke—she believed the microscope to be a useful tool for providing previously unconsidered views of natural phenomena. Indeed, scientists should use tools like the microscope to observe what they could not otherwise see. They should not, however, treat artificial observations as the only infallible records of truth, or imply that the human senses are in need of "reparation" or "purification.” Therein lay Cavendish's second major point of critique: the values experimental philosophers ascribed to new ways of seeing through the microscope, to the "pride of place" that came to be extended to empirical observation and that thus belittled other ways of knowing the surrounding world.7 Unlike Hooke, who offered readers of

${ }^{7}$ Literary scholar Tita Chico argues that Cavendish was in error when she pinpointed the weakness of the microscope. Cavendish was one who "implies that microscopes are a kind of plaything that have little to do with accurate perception," according to Chico $(2006,151)$. But such inaccuracy would have enamored experimental philosophers, as it proved the "monstrosity of nature"-to use Daston and Galison's 
Micrographia a practicum on how to reason through the microscope, Cavendish would offer readers of her Observations ways to speculate around epistemic theories and understand the natural world by attuning to it.

The Internal Substance of Natural Phenomena

If historians wish to find Cavendish's place in the history of ideas, they must consult her understanding of matter, which was more agential and vitalist than her counterparts, argues historian of science and philosophy Karen Detlefsen (Detlefsen 2018, 75). Because she distanced herself from Hobbes and Hooke in regard to distinctions between art and nature and the status of knowledge more generally, she would have to theorize a new understanding of matter as well. Recall that Hooke and Hobbes conveyed nature as mechanical and passive, that which could be revealed by human, artificial means. To counter this definition and infuse a greater sense of agency in nature, Cavendish would first have to show the limits of their mechanistic materialism. Her final point of contention with Hooke's Micrographia, then, was what exactly could come into view through the refractive lens of the microscope, what empirical philosophers could and could not view through the eyepiece.

Hooke's stance was that artificial means brought the internal substance of matter to view, or "the subtilty of the composition of Bodies, the structure of their parts, the various texture of their matter, the instruments and manner of their inward motions" to

phrase (2010, 67). Perception was indeed the issue for Cavendish, but her disavowal of the microscope had less to do with the importance of the scientific tool as with who was given access to reason through its means, whose perception mattered. If microscopy came to be the only valued observation, then women's observations through contemplative philosophy would come to be dismissed. 
light (Hooke 1665, 21). By contrast, Cavendish was adamant that the microscope could only observe the external aspects of objects under study. Internal substance-or the unique patterns subsisting within an object, giving the object its vitality-was not something that could be assessed through microscopy. Hooke, and most other experimental philosophers, would not entertain this point, but on this idea Cavendish placed her only direct assurance in Observations. "Of this I am confident," she stated, "that this same art, with all its instruments, is not able to discover the interior natural motions of any part or creature of nature" (Cavendish 1666b, 5o, emphasis added). Motion, as we will see, was of vital importance for Cavendish's optics and theory of matter-motion not passively imparted from another source, as was the case in Hobbes's mechanistic materialism, but motion actively initiated from within matter itself. The microscope, by contrast, required that motion be stilled, a requirement that brings Frédérique Aït-Touati to call Hooke’s microscopic images "still lives," as in still life paintings (Aït-Touati 2011, 150). Therefore, for Cavendish, if the internal substance of matter was vital, living, and moving, then observing a static slice of those objects could never fully convey that vitality.

Sarasohn pinpoints the beginnings of this vital materialism in Cavendish's Philosophical Letters (1664) through her contradictions of Hobbes's mechanistic materialism (Sarasohn 2003, 41). Like Hobbes, Cavendish believed that matter was in constant in motion-the two thinkers diverged, however, when it came to "the extent to which matter and mankind may be described as free, either to move or to choose" (Sarasohn 2003, 41). In Hobbesian materialism, particles did not move in and of 
themselves; physical causation was required for particles to hit one another (Sarasohn 2003, 46). Cavendish's materialism, on the other hand, assigned traits to matter usually associated with human agency: "it moves, it senses, it reasons, it is free" (Detlefsen 2007, 188). This freedom, Sarasohn further explains, is extended because of matter's self-moving tendencies (Sarasohn 2003, 48). Placing matter in self-moving motion not only extended radical agency to nature, but in doing so also extended greater agency and reputability to women in their "natural state." Cavendish authored such theories for just that reason: "the actual world [she] lived in was not free and natural" (Sarasohn 2003, 53). Instead, her social world "resembled more closely Thomas Hobbes's artificial state where motion, and freedom, is constrained" (Sarasohn 2003, 53). It was this vital materialism that allowed Cavendish to speculate around the mechanistic fate of women in early modern England and anticipate alternate epistemologies.

Cavendish thus turned to contemplative philosophy as the best method for studying interiors, and the human eye-without interference from artificial means-was shown as the best method for studying exteriors. The human eye, for Cavendish, was more than just its faulty lens-it was a networked, holistic system inextricable from cognition. As she explained, "The best optic is a perfect natural eye, and a regular sensitive perception; and the best judge, is reason; and the best study, is rational contemplation joined with the observations of regular sense, but not deluding arts" (Cavendish 1666b, 53, emphasis added). With each additional artificial lens of the microscope, there was more opportunity for distortion. And those most susceptible to the danger of the microscope were those who were unaware of what was and was not 
distorted, namely women and individuals of lower classes who lacked access to the education and empirical tools needed to test their hypotheses.

To present a theory of sensation (and perception) that allowed those with artificial means to adequately peer into nature's internal substance, Cavendish would create her own optics, an optics involving less visual distortion and privileging everyday ways of seeing. This optics would extend ancient theories of sight through a redefinition of mimesis in order to explain a radical agency that considered an inner life or vitality within every physical entity. It would maintain that seeing the physical structure of objects through a microscope did not equate to knowing their vitality. It would maintain that any human observer could witness the vitality of natural phenomena without artificial means. Finally, it would theorize a practice for seeing and languaging alongside natural phenomena - rather than reasoning about, outside, or around them-a practice Cavendish would come to call "patterning."

\section{Patterned Optics and Sensory Mimesis}

To base experimental conclusions only on microscopic views risked ignoring the holistic body surrounding that material viewed in cross section. Indeed, the foundational idea underlying Cavendish's optics was a certain notion that matter consisted of vitalpossibly agential—energy. A fundamental premise underlying her contention with Hooke's optics was that the human was not the only active participant in scientific observation. Matter, too, that "stuff" that made up the building blocks of "objects," was also moving, living, speaking. As this section details, matter became an actor in Cavendish's scientific epistemology, an epistemology displaying an agential personhood 
of sorts that attempted to expand agency beyond the mechanistic systems of Hobbes and Hooke. Cavendish's optics, then, hoped for a way of seeing in which both observer and the object of study existed in a synoptical network of relations. Such synopsis derived not from a bird's eye view or a "still life," but instead from recognition that human visual perception was indebted to a multiplicity of acting agents. This expansive agency was part of the reason that mimesis-here the drama that unfolded in nature and the process that structured the "communicative" practices among and between agents in nature-played a central role in Cavendish's optics. Not often does a theory of optics intersect with the history of rhetoric, but here a scientific epistemology is made possible because the rhetorical concept of mimesis could be molded to expand agency in early modern metaphysics.

To theorize vision as viewing the vitality of matter and as a sensory process rooting human observers in their bodies, Cavendish defined sight as the "pattern[ing] out" of "perceptive motions in the optic sense" (Cavendish 1666b, 147). For Cavendish, "patterns" had to do with the ability of sense organs to create internal motions in the form of a pattern of a perceived external object (Cunning 2019, 18). What exactly was "patterned out" by the eye had to do with the vital internal substance of particular objects. ${ }^{8}$ According to Cavendish, every object was composed of a certain vital makeup, and that

${ }^{8}$ The idea of "patterning" may also evoke notions of quilt making. Much research has been written on quilting as a feminist embodied and communicative practice-see, for example, Elsley (1990), Fisk (2012), and Witkowski (2014). Most relative to this study is biologist Maura C. Flannery's (2011) depiction of quilting as a feminist metaphor for how scientific inquiry may most ethically progress. 
vitality manifested though "internal motions" performed as part of its being (there). Vision occured when an observer detected the internal pattern being performed by an object and relayed that patterned performance to the mind. This process of mimetic patterning ensured for Cavendish that every observer was indebted to the synoptic performance of their object of study, in contradistinction to Hooke's optics that would place the human observer as viewing only a portion of the object in miniscule form. Not only did Cavendish resist the static specimen beneath the microscope, she further resisted a static observation, calling attention instead to the bodily, sensing work required of the observer. In this optics of patterning and ever-changing, ever-in-flux motion, seeing became more imitation than observation.

From her earliest writings, the rhetorical concept of mimesis, or "imitation," as she often called it, was central to how Cavendish conceived of sensation, especially visual perception. Yet, in keeping with the rhetorical tradition of her time, Cavendish learned the concept of mimesis in the context of rhetoric and poetics. That is, the primary use of "imitation" in The World's Olio involved the traditional rhetorical notion of imitation as a "copy." As she put it: "A good Imitation is good, and Those are to be commended that copy well an excellent original" (Cavendish 1655, Book II, Part i). "Yet," Cavendish continued, clarifying that patterns are what individuals copy during imitation, "it expresseth want of Invention that They cannot draw without a Pattern." Later in The World's Olio, Cavendish spoke again of the differences between imitation and invention, in that instance mentioning "Rhetorick" specifically (Cavendish 1655, Book II, Part i). 
Cavendish nevertheless employed the concept of "imitation" in a different valence elsewhere in the treatise to explain how the mind processes information from the senses:

There is nothing in the understanding, that is not first in the senses.... The senses bring all the materials into the brain, and then the brain cuts and divides them, and gives them quite other forms, then the senses many times presented them.... When the brain works upon her own materials, and at home, it is called poetry and invention, but when the brain receives and words journey-work, which is not of its own materials, then it is called learning, and imitation. (Cavendish 1655 , Book I, Part i)

This passage shows the early stages of Cavendish's theory of mimetic patterning, with the brain receiving and imitating materials "which [are] not its own."

Mimesis in ancient rhetoric most often references the use of a paradigm case that is imitated by a student. ${ }^{9}$ Of course, Cavendish was not the first to turn to mimesis for its malleability in describing the fluid demarcations between external phenomena and internal perception. Historians of rhetoric generally identify three meanings for mimesis: the Platonic notion of images as copies of ideal truth; the Aristotelian notion of poetics as representations of human action; and the pedagogical notion of copying, simulating, or emulating models (Corbett 1971, 243; Farrell 1986, 8-11; Haskins 2000). Eric Havelock admits, however, that mimesis may be "the most baffling of all words in [Plato's] philosophic vocabulary," given how the philosopher initially applied the term to drama but then "seems to enlarge [the term] to cover several other phenomena" (Havelock 1982,

${ }^{9}$ There is much evidence to suggest that Cavendish would have had a robust understanding of ancient rhetorical writers and thus conceptions of mimesis. In her analysis of Cavendish's books, Crawford uncovers the expert knowledge Cavendish had of ancient Greek and Roman authors like Plutarch, Thucydides, and Livy, authors of whom Cavendish often denied having knowledge (Crawford 2018, 95). Crawford argues that Cavendish's reticence in that regard signaled a certain political positioning. 
20). Addressing the various iterations of the term in ancient rhetoric, John Muckelbauer articulates that mimesis captured "the dynamics through which [a] model is encountered in order to be imitated, in order to produce some kind of copy" (Muckelbaur 2003, 67). Beyond the reproduction or variation of a model, mimesis also addressed the idea of inspiration, of change evoked from the model (Muckelbaur 2003, 83-85). In describing the ancient rhetorical aspect of mimesis relating to inspiration, Muckelbauer captures the essence of Cavendish's own expansion of the term. This aspect of mimesis introduced a complication to "the dialectical relation between subjects and their models" (Muckelbauer 2003, 83). As Muckelbauer explains, "the model here is not encountered as content at all.... Instead, in the act of inspiration, the model transmits only inspiration itself, it transmits the very capacity to be carried out of oneself" (Muckelbauer 2003, 8586). Muckelbauer finds this articulation of mimesis in how ancient writers spoke of the muses, but the idea of a transmission of inspiration, a transmission of sensory information rather than exact representation, is certainly echoed in Cavendish's own use of the term. As her theory of sensory mimesis implied, human observers come to "know" non-human matter not through the literal copying of their patterns, but through imitation of them.

In turning to mimesis, Cavendish not only harnessed the concept's roots in ancient rhetoric but also participated in the Renaissance uses of the term that informed theories of personhood, including Hobbes's “artificial man." Such theories of personhood, explains historian Quentin Skinner, contended with how an individual could act in or bear the name of someone else, or, in Hobbes's case, the commonwealth $(1999,6)$. And in the time 
of Hobbes and Cavendish the idea of acting in the name of another was caught up with the "dramatis personae on the stage" (Skinner 1999, 6), which implied various layers of mimesis in personhood, i.e, where the "natural" ended and performance, or the "artificial" began. As Skinner shows, mimesis became central to Hobbes's theory of man, as Hobbes wrote: "a Person, is the same that an Actor is, both on the Stage and in common Conversation" $(1999,6)$. In other words, all the world was a stage to Hobbes, and this idea circulated widely in his time (Skinner 1999, 12). Whether Cavendish's adoption of mimesis to define sensation and agential matter derived from Hobbes is less important than knowing that the concept of performance was a powerful social idea that fell on interested ears during her time. Staging in the seventeenth century, drama scholar Rebecca D'Monte further explains, lent itself to theories of personhood and identity because performance was seen as a way to recreate the self $(2003,109)$. For Hobbes, mimesis allowed man to overcome his natural state. For Cavendish, mimesis offered a way to rethink early modern metaphysics.

Cavendish's reappropriation of the term for scientific use, presented mimesis, orin this case-mimetic patterning, as opponent to the recreation or reproduction of objects through mechanical means, and proponent to the rhetorical encounter in which the seer imitates, and thus more immediately responds to, objects in the natural world. To put it another way, Cavendish's optics might have been based on mimesis, but did not presume that vision directly represented the outside world. Instead, to see was to perform an internal conception of the outside world. In defining vision as "patterns of motion," seeing became less a process of acting on an object but acting with that object. 
In Philosophical Fancies (1653), written just two years prior to The World's Olio, Cavendish worked out her conception of how sensation was the process wherein the mind copied patterns from material objects. There, she described this unique "pattern" of vital movement within objects as dancers on a dance floor. Just as with the repetition of movements performed by dancers, she insisted, the pattern exuded by an object could be traced as if it were unfolding on a ballroom floor (Marshall 2016, xvii). In visual perception, the "rational spirits" of an observer witnessed the dance that is internal and unique to an object and then replicated, or imitated, that dance for the brain. By dancing the same dance, the mind comes to "know" the object. And an observer could never "know" the object only through observation, but through this mimetic patterning of the object. As the years progressed, Cavendish replaced the dance metaphor with the language of "patterns" or "imitations" to more explicitly describe the visual process (Marshall 2016, xvii).

By the time of Observations, Cavendish relied upon "imitation" and patterning to explain the play of the senses, or how visual signals moved from the external world into the internal mind. Literary scholar Lisa Walters considers Cavendish's concept of "patterning" as working counter-logically to ancient theories of vision in which force was necessary for sight $(2014 \mathrm{~b}, 377){ }^{10}$ In the Platonic extramission theory of vision-most

${ }^{10}$ Force is a contentious issue in theories of vision. The Royal Society's optics of objectivity, in which the observer acts upon objects but is never acted upon, recalled Platonic theories of vision. This similarity has led feminist literary critics to connect thinkers from the Royal Society, such as Francis Bacon, with the concept of the "male gaze." As Walters explains: "Though Bacon suggests that scientists have not been able to dominate Nature, she is none the less imagined as a female body to penetrate and violate by male reason for the pursuit of knowledge. The male/female binary is utilized to 
notably presented in the Timaeus (Plato 200o) — the force of vision rested with the observer: beams were thought to exude from the observer's eyes in order to reach out and "grab" the beams exuded from the object. In this process of reaching out to "grab" the object in order to perceive it, the observer altered the nature of the object. By contrast, Aristotle's intromission theory of vision, as expounded in the De Anima (Aristotle 2016), contended that the observer was completely passive and that the force in vision rested with the external world. That is, beams from the object jumped into the eyes and mind of the observer. The only thing an observer could do to halt this process was to close their eyes.

Cavendish's theory of optics, however, struck a balance between the two: objects certainly exuded "patterns" (otherwise considered "beams") and thus had agential force in portraying how they were perceived, but the observer also maintained agency in that she must consciously imitate this pattern in order to see or know the object. Vision, in this schema, was not merely about projecting or receiving a static representation of the world, but about dancing along with the world. Cavendish herself dispelled "transmission" optical theories in Observations, asserting instead her "opinion ... that the most rare and subtlest parts in the animal sensitive organs, do pattern out the figures of exterior objects, and that the perception of the exterior animal senses, to wit, sight, hearing, tasting, touching, smelling, is certainly made by no other way, than by figuring and imitation" (Cavendish 1666b, 174-175, emphasis added). In short, sensation, and how the brain

portray a relation between knowledge and sexual power. Power can be obtained over Nature as man has power over woman" (Walters 2014a, 63). 
processes sensory information through perceptual processes, involved mimetic interaction with the natural world. Unlike ancient theories of vision or the Royal Society's optics, which hinged upon artificial means to validate or provide factual "proof" for a now expert observer, Cavendish's optics consisted of visual perception based on patterning or mimesis, on an embodied observer who was always entwined with or indebted to that which she observed.

This use of mimesis to build an alternative theory of optics certainly involved a conception of agency that extended beyond the bounds of the human for Cavendish. During acts of vision or perception, the interplay between external and internal, agent and object shifted:

When I say that the 'exterior object is the agent; and the sentient body, the patient': I do not mean, that the object does chiefly work upon the sentient, or is the immediate cause of the perception in the sentient body, and that the sentient suffers the agent to act upon it; ... . I am quite of a contrary opinion, to wit, that the sentient body is the principal agent, and the external body the patient; for the motions of the sentient in the act of perception, do figure out or imitate the motions of the object, so that the object is but as a copy that is figured out, or imitated by the sentient, which is the chief agent in all transforming and perceptive actions that are made by way of patterning or imitation. (Cavendish 1666b, 18, emphasis added)

Placing both object and observer as acting agents in visual perception, Cavendish not only brought these agents together in close proximity, but she also used mimesis as the mechanism by which to understand sensory encounters, to understand the communicative exchange between human and nonhuman matter. ${ }^{11}$ And considering

${ }^{11}$ This communicative exchange, Cavendish made clear, does not occur in conscious, voluntary channels. As she put it, "The actions of imitation or patterning, are different from the voluntary actions" of other bodily functions like "expulsion" (Cavendish 
Cavendish's optics of mimetic patterning as a theory of rhetorical communication need not seem anachronistic, especially considering that Cavendish herself explained patterning as "the perpetual commerce and intercourse between parts and parts" (Cavendish 1666b, 140, emphasis added). Thus, we can understand Cavendish's use of "imitation" and patterning as an expansion and redefinition of rhetorical mimesis for use in scientific epistemologies, explaining ways of relation between human and nonhuman matter.

That Cavendish initially conceived of this optics of patterning and the process of visual perception as sensory mimesis through dance is telling. This metaphor of dance was one of multiple valences for Cavendish that became more enriched with each iteration of her optics, even once the language of dance, of explicit performance, fell away and only the language of "patterns" and "imitation" remained. At its core, the metaphor speaks to the insistence of partnerships in early modern English dances, partnerships in which each partner had assigned steps but the freedom to perform those steps as they desired. As Boyle explains: "While dances typically follow a certain pattern or set of rules, they are performed by intelligent creatures who may choose whether or not to follow the rules of the dance" (Boyle 2018, 68). With the interaction between humans and nonhuman matter during vision described as a dance, nonhuman matter is ascribed a degree of agency that counters the mechanistic metaphors of experimental philosophy in which nature is depicted as a machine or a clock (Boyle 2018, 68).

1666b, 35). Patterning, instead, happens on a different register, often, she implied, unbeknownst to the conscious mind. 
Cavendish's optics, then, stood in stark contrast to other metaphysics and scientific epistemologies of her time by privileging a woman's way of interacting with the world, a way of listening to and languaging alongside nonhuman matter. Hooke, of course, with his microscope, would go on pave the road for microbiology, a field necessary for the study of human diseases. Cavendish's writings, admittedly, made no such changes to histories of science, but her aims were not based in the establishment of empirical facts as much as they were about how those facts were ascertained and who was given authority and access to establish them. And it is worth noting that only in the wake of feminist new materialisms, cognitive neuroscience, and the championing of alternative epistemologies have Cavendish's ideas begun to sound especially prescient. Detlefsen has shown that Cavendish's theories of nature presage at least "one contemporary feminist account within the philosophy of science, that offered by Evelyn Fox Keller" (Detlefsen 2018, 73). Cavendish's choice of the keyword "pattern" too is consistent with the work of contemporary neuroscientists like Howard Gardner, Margaret Livingstone, and Semir Zeki, all of whom study the visual brain. Gardner uses the language of "patterning" most explicitly when he discusses how knowledge is stored neurally (Gardner 1983, 152), and Zeki contends that the brain creates patterns from past visual experiences and then interprets present sensory stimuli according to those patterns (Zeki 1999, 5-6). Further still, Cavendish's metaphor of the "pattern" animates and makes agential the building blocks of matter, theories legitimized by feminist new materialisms and the findings of quantum physics in the last several decades (Barad 2007; Bennett 2010). Now an important concept for contemporary sciences, Cavendish's turn to "patterning" allowed 
her to anticipate key premises in feminist science studies and envision the interaction between human and nonhuman matter in scientific encounters in both its conceptual and material valences through the rhetorical concept of mimesis.

\section{The Rhetorical Effect of Optics as Mimetic Patterning}

When Cavendish received the invitation to attend a Royal Society meeting in May 1667, she exemplified the confidence that came from her mimetic epistemology, from the idea that objects seen as other, whether metaphorically or through the microscope, play active rhetorical roles. As was mentioned at the onset, most scholars have considered Cavendish's natural philosophy too imaginative to be scientific and her visit to the Royal Society too timid to be a success. Now, with the additional evidence of Cavendish's critique of the Royal Society, her overturning of early modern metaphysics, and her mimetic optics, we may return to a critically imaginative reading of that visit, one that allows us to consider the possibility that Cavendish recognized the mimetic dynamic at play that day. In such a critically imaginative reading, it becomes less important whether Cavendish was rhetorically persuasive and more important that we observe how she turned to the rhetorical concept of mimesis for confidence in confronting the optics of the Royal Society.

That is, knowing that members of the Royal Society were to place her "under the microscope," perhaps Cavendish presented herself before the experimental philosophers as an object worthy of study and performed in such a way as to resist their being able to know or understand her. Members of the Royal Society would study her like their specimens: as a static object upon which to gaze, not as a living subject from which to 
learn. Literary scholar Kate Lilley once touted Cavendish as "an exemplary instance of woman as spectacle" (Lilley 1992, ix). This role of spectacle, best captured through her nickname, "Mad Madge," was "dependent on the exhibition of herself for the benefit of an audience," argues D’Monte (2003, 120). Instead of trying to persuade Society members that she was a reputable natural philosopher-an impossibility in their estimationCavendish leaned into the role of "Mad Madge" because this position of other, she knew, would demand attention, if not a response.

But it would also not be too bold to suggest that Cavendish exposed the limits of the Royal Society's optics: if an object is studied only beneath a microscope, metaphorically or otherwise, there is no way to conclude its substance. Had Cavendish spoken her mind that day, she likely would have slipped from being an object of study to an object of ridicule. Through her performance of silence, she placed herself at a distance, performing the role of object-under-study-by-experimental-philosophy. Even in her theories of rhetoric, Cavendish understood that the body often speaks louder than words: "It is true that there are more errors committed in speaking [than] in silence.... There is an old saying, to talk much and well is seldom heard" (Cavendish 1655, Book I, Part i 52). And whereas Cavendish's theories may only recently be finding scholarly and scientific resonances, her performance did, indeed, command attention. Weeks later, Royal Society members were still talking about Cavendish's presence at Arundel-house. In the early weeks of June 1667, the Council proposed that gifts be extended to those who "had taken pains in fitting the room for the late entertainment of the Duchess of Newcastle" (Royal Society 1667 ). Given the widespread attention garnered by her visit, it is not too much a 
stretch of the imagination to suspect that this visit and Cavendish's frequent publishing on experimental philosophy inflected with contemplative, embodied ways of knowing had ripple effects that allowed women to participate more frequently and confidently in scientific conversations. After all, as Chelsea Redeker Milbourne and Sarah Hallenbeck show, later iterations of the microscope, such as the pocket microscope of the eighteenthcentury, would allow women to become discoverers of nature and participants in a science that was more "accessible, personal, and embodied" (Milbourne and Hallenbeck 2013, 412). Cavendish, it seems, anticipated, if not foreshadowed, feminist overturnings of hegemonic scientific epistemologies.

The objective observer emerging around Hooke's microscope in early modern England excluded women from scientific ways of knowing in that it "placed less importance on the embodied performances of the users and their personal reflections or opinions about the scientific process" (Milbourne and Hallenbeck 2013, 418). ${ }^{12}$ Cavendish presents an instance of one who subverted that scientific tradition as it emerged, an instance of a woman who invited other women to theorize alternative methods for scientific discovery through her own remaking of agency and materialism. She offers an early rhetorics of science in which alternative epistemologies—-here, embodied and intuitive ways of knowing—might critique mechanical, experimental processes. Perhaps more pointedly, Cavendish's optics, and the redefinition of rhetorical mimesis that

12 See Daston and Galison (2010) for an overview of the debate about the origins of objectivity and the role played by Royal Society members in determining the evolution of visual practices in scientific argumentation. 
enlivened it, offers a historical moment in which rhetoric offered tools for scientists to think with, thus hinting at rhetorics in science, not just rhetorics of science. 


\section{Works Cited}

Aït-Touati, Frédérique. 2011. Fictions of the Cosmos: Science and Literature in the Seventeenth Century, translated by Susan Emanuel. Chicago, IL: The University of Chicago Press.

Ankers, Neil. 2003. "Paradigms and Politics: Hobbes and Cavendish Contrasted." In $A$ Princely Brave Woman: Essays on Margaret Cavendish, Duchess of Newcastle, edited by Stephen Clucas, 242-254. Hampshire, England: Ashgate.

Aristotle. 2016. De Anima, translated by Christopher Shields. New York, NY: Oxford University Press.

Barad, Karen. 2007. Meeting the Universe Halfway: Quantum Physics and the Entanglement of Matter and Meaning. Durham, NC: Duke University Press.

Battigelli, Anna. 2015. Margaret Cavendish and the Exiles of the Mind. Lexington, KY: The University Press of Kentucky.

Bennett, Jane. 2010. Vibrant Matter: A Political Ecology of Things. Durham, NC: Duke University Press.

Birch, Thomas. 1756. The History of the Royal Society of London for Improving of Natural Knowledge. Vol. 2. Internet Archive.

https://archive.org/details/historyofroyalsoooozbirc/page/178/mode/2up.

Bowerbank, Sylvia. 1984. “The Spider's Delight: Margaret Cavendish and the 'Female' Imagination." English Literary Renaissance 14 (3): 392-408. https://doi.org/10.1111/j.1475-6757.1984.tboo872.x.

Boyle, Deborah. 2018. The Well-Ordered Universe: The Philosophy of Margaret Cavendish. New York, NY: Oxford University Press.

Broad, Jacqueline. 2011. "Is Margaret Cavendish Worthy of Study Today?" Studies in History and Philosophy of Science 42: 457-461. https://doi.org/10.1016/j.shpsa.2011.02.004.

Cavendish, Margaret. 1653. Philosophical Fancies. Digital Cavendish. http://digitalcavendish.org/complete-works/philosophical-fancies-1653/.

Cavendish, Margaret. 1655. The World's Olio. Digital Cavendish. http://digitalcavendish.org/complete-works/worlds-olio-1655/.

Cavendish, Margaret. 1663. Orations of Divers Sorts. HathiTrust. 
Cavendish, Margaret. 1664. Philosophical Letters. Digital Cavendish. http://digitalcavendish.org/resources/letters-in-the-philosophical-letters/.

Cavendish, Margaret. (1666b) 2001. Observations upon Experimental Philosophy, edited by Eileen O'Neill. Cambridge, UK: Cambridge University Press.

Chico, Tita. 2006. "Minute Particulars: Microscopy and Eighteenth-Century Narrative." Mosaic 39 (2): 143-161. ProQuest.

Corbett, Edward P.J. 1971. "The Theory and Practice of Imitation in Classical Rhetoric." College Composition and Communication 22 (3): 243-250. http://www.jstor.com/stable/356450.

Crawford, Julie. 2018. "Margaret Cavendish's Books." In Women's Bookscapes in Early Modern Britain, edited by Leah Knight, Micheline White, and Elizabeth Sauer, 91114. Ann Arbor, MI: University of Michigan Press.

Cunning, David. 2017. "Margaret Lucas Cavendish.” In The Stanford Encyclopedia of Philosophy, edited by Edward N. Zalta. https://plato.stanford.edu/archives/sum2017/entries/margaret-cavendish/.

Cunning, David. 2019. Margaret Cavendish: Essential Writings. New York, NY: Oxford University Press.

Daston, Lorraine, and Peter Galison. 2010. Objectivity. New York, NY: Zone Books.

Detlefsen, Karen. 2007. "Reason and Freedom: Margaret Cavendish on the Order and Disorder of Nature." Archiv für Geschichte der Philosophie 89(2): 157-191. https://doi.org/10.1515/AGPH.2007.008.

Detlefsen, Karen. 2018. "Margaret Cavendish on Laws and Order." In Early Modern Women on Metaphysics, edited by Emily Thomas, 72-91. Cambridge: Cambridge University Press.

D’Monté, Rebecca. 2003. “'Making a Spectacle': Margaret Cavendish and the Staging of the Self." In A Princely Brave Woman: Essays on Margaret Cavendish, Duchess of Newcastle, edited by Stephen Clucas, 109-126. Hampshire, England: Ashgate.

Elsely, Judith. 1990. “The Semiotics of Quilting: Discourse of the Marginalized.” PhD Dissertation, University of Arizona. http://hdl.handle.net/10150/565534.

Fahnestock, Jeanne. 1999. Rhetorical Figures in Science. New York, NY: Oxford University Press. 
Farrell, Thomas B. 1986. "Rhetorical Resemblance: Paradoxes of a Practical Art." Quarterly Journal of Speech 71(1): 1-19. https://doi.org/10.1080/00335638609383755.

Fisk, Anna. 2012. “To Make, and Make Again': Feminism, Craft and Spirituality.” Feminist Theology 20 (2): 16o-174. https://doi.org/10.1177/0966735011425302.

Flannery, Maura C. 2011. "Quilting: A Feminist Metaphor for Scientific Inquiry.” Qualitative Inquiry 7 (5): 628-645. https://doi.org/10.1177/107780040100700507.

Gardner, Howard. (1983) 2004. Frames of Mind: The Theory of Multiple Intelligences, $\mathbf{2 0}^{\text {th }}$ anniversary edition. New York, NY: Basic Books.

Gross, Alan. 2016. "The Limits of the Rhetorical Analysis of Science." Poroi 12(1): 1-28. https://doi.org/10.13008/2151-2957.1244.

Haskins, Ekaterina V. 200o. "Mimesis Between Poetics and Rhetoric: Performance Culture and Civic Education in Plato, Isocrates, and Aristotle." Rhetoric Society Quarterly 30 (3): 7-33. https://doi.org/10.1080/02773940009391180.

Havelock, Eric A. (1963) 1982. Preface to Plato. Cambridge, MA: Harvard University Press.

Hooke, Robert. (1665) 1987. Micrographia, or Some Physiological Descriptions of Minute Bodies Made by Magnifying Glasses, facsimile edition. Lincolnwood, IL: Science Heritage, Ltd.

Hutton, Sarah. 1997. "In Dialogue with Thomas Hobbes: Margaret Cavendish's Natural Philosophy.” Women's Writing, 4(3): 421-432. https://doi.org/10.1080/09699089700200024.

Hutton, Sarah. 2003. "Margaret Cavendish and Henry More." In A Princely Brave Woman: Essays on Margaret Cavendish, Duchess of Newcastle, edited by Stephen Clucas, 185-198. Hampshire, England: Ashgate.

Jack, Jordynn. 2009. "A Pedagogy of Sight: Microscopic Vision in Robert Hooke's Micrographia.” Quarterly Journal of Speech 95 (2): 192-209. https://doi.org/10.1080/00335630902842079.

James, Susan. 2018. "Hermaphroditical Mixtures': Margaret Cavendish on Nature and Art." In Early Modern Women on Metaphysics, edited by Emily Thomas, 31-48. Cambridge: Cambridge University Press. 
Keller, Eve. 1997. "Producing Petty Gods: Margaret Cavendish's Critique of Experimental Science." English Literary History 64 (2): 447-471. https://doi.org/10.1353/elh.1997.0017.

Kennedy, George A. 1999. Classical Rhetoric and Its Christian and Secular Tradition from Ancient to Modern Times, $2^{\text {nd }}$ edition. Chapel Hill, NC: The University of North Carolina Press.

Knellwolf, Christa. 2001. "Robert Hooke's Micrographia and the Aesthetics of Empiricism." The Seventeenth Century 16 (1): 177-200. ProQuest.

Knight, Leah, Micheline White, and Elizabeth Sauer, editors. 2018. Women's Bookscapes in Early Modern Britain. Ann Arbor, MI: University of Michigan Press.

Lawson, Ian. 2015. "Bears in Eden, or This is Not the Garden You're Looking For: Margaret Cavendish, Robert Hooke and the Limits of Natural Philosophy." The British Journal for the History of Science 48 (4): 583-605. https://doi.org/10.1017/Soo07087415000588.

Lawson, Ian. 2016. "Crafting the Microworld: How Robert Hooke Constructed Knowledge about Small Things." Notes and Records: The Royal Society Journal of the History of Science 70: 23-44. https://doi.org/10.1098/rsnr.2015.0057.

Lilley, Kate. 1992. Editor's Introduction to The Description of a New World, Called the Blazing World, by Margaret Cavendish. New York, NY: New York University Press.

Livingstone, Margaret. 2002. Vision and Art: The Biology of Seeing. New York, NY: Harry N. Abrams.

Marshall, Eugene. 2016. Introduction to Observations upon Experimental Philosophy, by Margaret Cavendish. Indianapolis, IN: Hackett Publishing.

Milbourne, Chelsea Redeker, and Sarah Hallenbeck. 2013. "Gender, Material Chronotopes, and the Emergence of the Eighteenth-Century Microscope." Rhetoric Society Quarterly 43 (5): 401-424. https://doi.org/10.1080/02773945.2013.828096.

Mintz, Samuel I. 1952. "The Duchess of Newcastle's Visit to the Royal Society.” The Journal of English and Germanic Philology 51 (2): 168-176. JSTOR.

Muckelbauer, John. 2003. "Imitation and Invention in Antiquity: An HistoricalTheoretical Revision." Rhetorica 21 (2): 61-88. 
Nate, Richard. 2001. "Plain and Vulgarly Express'd': Margaret Cavendish and the Discourse of the New Science." Rhetorica 19 (4): 403-417. https://doi.org/10.1525/rh.2001.19.4.403.

O'Gorman, Ned. 2013. "Hobbes, Desire, and the Democratization of Rhetoric." Advances in the History of Rhetoric 16 (1): 1-28. https://doi.org/10.108o/15362426.2013.763737.

O’Neill, Eileen. 2005. "Early Modern Women Philosophers and the History of Philosophy." Hypatia 20 (3): 185-197. muse.jhu.edu/article/18499o.

Pepys, Samuel. (1667) 1974. The Diary of Samuel Pepys, volume 8, edited by Robert Latham and William Matthews. Berkeley, CA: University of California Press.

Plato. 20oo. Timaeus, edited by Donald J. Zeyl. Indianapolis, IN: Hackett Publishing.

Popkin, Richard H. 1988. "Theories of Knowledge.” In The Cambridge History of Renaissance Philosophy, edited by Charles B. Schmitt, Quentin Skinner, Eckhard Kessler, and Jill Kraye, 668-684. Cambridge: Cambridge University Press.

Rogers, John. 1996. The Matter of Revolution: Science, Poetry, and Politics in the Age of Milton. Ithaca, NY: Cornell University Press.

Royal Society of London. n.d. "History of the Royal Society." Accessed December 5, 2017. https://royalsociety.org/about-us/history/.

Royal Society of London. 1667. June 3, 1667, Meeting Minutes, Repository GB 117 The Royal Society, Ref. No. CMO/1/131. Accessed July 22, 2020.

Royster, Jacqueline Jones, and Gesa E. Kirsch. 2012. Feminist Rhetorical Practices: New Horizons for Rhetoric, Composition, and Literacy Studies. Carbondale, IL: Southern Illinois University Press.

Sarasohn, Lisa T. 1984. "A Science Turned Upside Down: Feminism and the Natural Philosophy of Margaret Cavendish." Huntington Library Quarterly 47 (4): 289-307. https://doi.org/10.2307/3817365.

Sarasohn, Lisa T. 2003. "Leviathan and the Lady: Cavendish's Critique of Hobbes in the Philosophical Letters." In Authorial Conquests: Essays on Genre in the Writings of Margaret Cavendish, edited by Line Cottegnies and Nancy Weitz, 40-58. Cranbury, NJ: Fairleigh Dickinson University Press.

Skinner, Quentin. 1999. “Hobbes and the Purely Artificial Person of the State.” The Journal of Political Philosophy 7 (1): 1-29. https://doi.org/10.1111/1467-9760.00063. 
Skouen, Tina, and Ryan J. Stark. 2015. Introduction to Rhetoric and the Early Royal Society: A Sourcebook. Leiden: Brill. ProQuest Ebrary.

Smith, A. Mark. 2015. From Sight to Light: The Passage from Ancient to Modern Optics. Chicago, IL: The University of Chicago Press.

Stark, Ryan John. 1999. "Margaret Cavendish and Composition Style." Rhetoric Review 17 (2): 264-281. JSTOR.

Sutherland, Christine Mason. 1997. "Aspiring to the Rhetorical Tradition: A Study of Margaret Cavendish." In Listening to Their Voices: The Rhetorical Activities of Historical Women, edited by Molly Meijer Wertheimer, 255-271. Columbia, SC: University of South Carolina Press.

Walters, Lisa. 2014a. Margaret Cavendish: Gender, Science, and Politics. Cambridge: Cambridge University Press.

Walters, Lisa. 2014b. "Optics and Authorship in Margaret Cavendish's Observations and The Blazing World." Viator 45 (3): 377-93. https://doi.org/10.1484/J.VIATOR.5.102933.

Walton, Craig. 1987. "Hobbes on the Natural and the Artificial." Hobbes's 'Science of Natural Justice,' edited by C. Walton and P.J. Johnson, 71-88. Dordrecht, The Netherlands: Martinus Nijhoff Publishers.

Weeks, Sophie. 2007. "Francis Bacon and the Art-Nature Distinction." Ambix 54 (2): 101129. https://10.1179/174582307X212332.

Whitaker, Katie. 2003. Mad Madge: The Extraordinary Life of Margaret Cavendish, Duchess of Newcastle, the First Woman to Live By Her Pen. New York, NY: Basic Books.

Witkowski, Jacqueline. 2014. "Ever Present, Never Presented: Suzanne Lacy, Feminism and Quilting." Master's Thesis, The University of British Columbia. https://doi.org/10.14288/1.0166975.

Wu, Hui. 2005. "The Paradigm of Margaret Cavendish: Reading Women's Alternative Rhetorics in a Global Context." In Calling Cards: Theory and Practice in the Study of Race, Gender, and Culture, edited by Jacqueline Jones Royster and Ann Marie Mann Simpkins, 171-185. Ithaca, NY: State University of New York Press.

Zeki, Semir. 1999. Inner Vision: An Exploration of Art and the Brain. New York, NY: Oxford University Press. 